\title{
The Molecular Cell Biology of Anterior Pituitary Cells
}

\author{
Arturo E. Gonzalez-Iglesias and Richard Bertram
}

Florida State University, Tallahassee, FL, USA

p0015 The dawn of neuroendocrinology is coincident with the beginning of the tale of a remarkable gland: the pituitary gland. Around AD 170 Galen postulated that the "pituita" (from the Greek ptuo, "to spit," and the Latin pituita, "mucus") secreted waste products (phlegm, one of the four humors of the body) from the brain into the nasal cavities. Nineteen centuries later, we have found not only that Galen's concept was far from the truth but also that a fascinating - yet still primitive - understanding of the gland has emerged.

p0020 The pituitary is one of the two elements that make up the hypothalamo-hypophysial unit, the joint anatomical structure comprising hormone-producing neurons and cells by which the brain regulates the vital functions of the body. Indeed, a key regulator of body homeostasis during development, stress, and other physiological processes, the pituitary gland acts as a double interpreter, mediating the talk between the brain and the peripheral organs, and integrating their respective cues as well as those of its own (local autocrine and paracrine factors). Being functionally and anatomically connected to the hypothalamus by the median eminence via the infundibular stalk, ${ }^{1}$ the pituitary has two embryologically and functionally distinct divisions: the neurohypophysis (or neural lobe) and the adenohypophysis (anterior pituitary and intermediate lobes). The remarkable molecular and cellular aspects of the biology of the cells that constitute the anterior pituitary is the focus of this chapter.

\section{ANTERIOR PITUITARY: ORGANIZATION, CELL TYPES, HORMONES AND FUNCTIONS}

s0015

The anterior pituitary is an endocrine gland responsible for secreting hormones that regulate a wide range of functions. These hormones 
are synthesized and released by distinct groups of polygonal endocrine cells that are organized as interlacing cords and lined up on an anastomizing web of capillary vessels (the secondary capillary plexus) derived from the hypophysial artery. The cytoplasm of these cells contains granules of stored hormone that are released by exocytosis. The endothelial cells of the capillaries are fenestrated to facilitate the exchange of molecules between the endocrine cells and the blood, which not only bring in the hypothalamic and peripheral factors (through the long portal vessels and hypophysial arteries, respectively) that regulate the activity of the gland but also carry the released pituitary hormones away into the general circulation. ${ }^{1}$ In addition, an extensive web of interconnected folliculostellate (FS) cells surround the endocrine cells. These cells regulate both the interaction of neighboring endocrine cells and the exchange of molecules between them and the capillaries. FS cells represent about 5-10\% of the anterior pituitary cell population.

p0030 The traditional view of the pituitary holds that there are five endocrine cell types that are responsible for synthesizing six anterior pituitary hormones (Table 2.1). For each cell type, several immortalized cell lines have been developed, characterized and used extensively. ${ }^{2}$

p0035 Somatotrophs, which synthesize and release growth hormone $(\mathrm{GH})$, are the major endocrine cell type in the anterior pituitary and constitute $40-50 \%$ of its cell population. They are localized predominantly to the lateral portions of the anterior lobe. Somatotroph function is primarily regulated by hypothalamic factors: growth hormone-releasing hormone (GHRH) produced by neurons in the arcuate nucleus is stimulatory, whereas somatostatin (STT) produced by neurons in the periventricular nucleus is inhibitory. STT suppresses both basal and GHRH-induced GH release, having no effect on GH synthesis. GH production and secretion also receives inhibitory feedback from the major target of $\mathrm{GH}$, insulin-like growth factor-I from the liver. Somatotrophs express receptors for many other regulators of GH synthesis and release, including ghrelin, pituitary adenylate cyclase-activating peptide, thyroid hormone, glucocorticoids, insulin and endothelins. GH is secreted from the somatotrophs at a pulse frequency of about $1-2 \mathrm{~h}$ with a half-life that ranges between $6-20 \mathrm{~min}$, and the pattern exhibits gender differences. In the case of males, the pulses are much larger early at night, whereas in females the pattern is more irregular and the pulses tend to be more uniform throughout the day. The pattern of GH release appears to be driven by the rate at which GHRH is released from the arcuate nucleus neurons.

GH is also called somatotropin (soma, p0040 "body") because of its profound and widespread anabolic effects throughout the body. In its absence, growth is stunted. Although virtually every tissue responds to some degree, skeletal muscle cells, liver, and chondrocytes (cartilage cells) are particularly sensitive to GH levels. Though the metabolic effects are direct actions of GH, it is now apparent that most, if not all, of the anabolic effects of GH are mediated by the production of a family of peptide hormone intermediaries known as insulin-like growth factors (IGFs) which are secreted by the liver, cartilage, muscle, and other tissues where they can act locally in a paracrine or autocrine fashion. $\mathrm{GH}$, acting through the IGFs, stimulates protein synthesis, cell growth and a positive nitrogen balance, leading to an increase in lean body mass and a decrease in body fat. Many hours must elapse after administration of GH before its anabolic, growthpromoting effects become evident.

Thyrotrophs comprise approximately 5\% of p0045 the anterior endocrine cell population and are typically spread over the anteriomedial and lateral portions of the gland. Thyrotrophs synthesize and secrete thyroid-stimulating hormone (TSH), also known as thyrotropin, which is controlled by central and peripheral 
t0010 TABLE 2.1 Hypothalamic Neurohormones and Anterior Pituitary Endocrine Cell Types and Hormones

\begin{tabular}{|c|c|c|c|}
\hline $\begin{array}{l}\text { Hypothalamic Releasing } \\
\text { or Inhibiting } \\
\text { Neurohormone }\end{array}$ & $\begin{array}{l}\text { Target Cell in } \\
\text { Anterior Pituitary } \\
\text { Gland }\end{array}$ & $\begin{array}{l}\text { Anterior Pituitary Hormone } \\
\text { Release Stimulated or } \\
\text { Inhibited }\end{array}$ & Target Anterior Pituitary Hormone \\
\hline $\begin{array}{l}\text { Growth hormone releasing } \\
\text { hormone (GHRH) }\end{array}$ & Somatotroph & Growth hormone (GH) & Multiple somatic tissues \\
\hline Somatostatin (STT) & & $\mathrm{GH}$ & Multiple somatic tissues \\
\hline $\begin{array}{l}\text { Thyrotropin releasing } \\
\text { hormone (TRH) }\end{array}$ & Thyrotroph & $\begin{array}{l}\text { Thyroid stimulating hormone } \\
\text { (TSH) }\end{array}$ & $\begin{array}{l}\text { Stimulates synthesis and release of } \\
\text { thyroid hormone by thyroid gland }\end{array}$ \\
\hline $\begin{array}{l}\text { Corticotropin releasing } \\
\text { hormone (CRH) }\end{array}$ & Corticotroph & $\begin{array}{l}\text { Adrenocorticotrophic hormone } \\
\text { (ACTH) }\end{array}$ & $\begin{array}{l}\text { Stimulates synthesis and release of } \\
\text { steroids by adrenal cortex }\end{array}$ \\
\hline $\begin{array}{l}\text { Gonadotropin releasing } \\
\text { hormone }(\mathrm{GnRH})\end{array}$ & Gonadotroph & $\begin{array}{l}\text { Follicle stimulating hormone } \\
\text { (FSH) and luteinizing hormone } \\
(\mathrm{LH})\end{array}$ & $\begin{array}{l}\text { Stimulates synthesis and release of } \\
\text { gonadal steroids, gametogenesis, } \\
\text { ovulation }\end{array}$ \\
\hline Dopamine & Lactotroph & Prolactin & $\begin{array}{l}\text { Milk synthesis and secretion by the } \\
\text { mammary gland }\end{array}$ \\
\hline
\end{tabular}

regulators. The dominant stimulatory control of thyrotroph function and TSH secretion is exerted by the hypothalamic neurohormone thyrotropin-releasing hormone (TRH) released by neurons of the paraventricular nucleus. TSH is secreted in pulses lasting for $2-3 \mathrm{~h}$ with a nocturnal surge before sleep. Once the sleep phase begins, TSH release is curtailed. The half-life of the hormone in blood is approximately of $1 \mathrm{~h}$.

p0050 TSH is a glycoprotein with a molecular weight of 28,000 and consists of a heterodimer of two subunits ( $\alpha$ and $\beta$ ) that are tightly associated by noncovalent forces and encoded by separate genes. Although both subunits are required for receptor binding and hormone action, the $\beta$ subunit confers biological specificity to the TSH molecule, as the $\alpha$ subunit is also a component of the anterior pituitary gonadotropin hormones luteinizing hormone (LH) and follicle-stimulating hormone (FSH). The essential actions of TSH are those exerted on the thyroid gland, where it promotes growth and differentiation of the gland and stimulates all steps in the secretion of the thyroid hormones thyroxine (T4) and triiodothyronine (T3). These steps include glandular uptake of iodide, its organification, the completion of thyroid hormone synthesis, and the subsequent release of thyroid gland products. T3 and T4 act at the hypothalamic and pituitary levels to block the secretion of TSH via feedback inhibition. Fasting decreases thyrotroph responsiveness to $\mathrm{TRH}$, while exposure to cold increases it.

Corticotrophs constitute about $15 \%$ of the adenohypophysial endocrine cell population and are scattered throughout the anterior lobe in adult animals, but are primarily found in the anteromedial part of the gland. They synthesize proopiomelanocortin (POMC) and release its proteolytic derivatives, adrenocorticotropin hormone $(\mathrm{ACTH}), \alpha$-melanocyte-stimulating hormone ( $\alpha-\mathrm{MSH})$, lipotropic hormone (LPH) and endorphins. The main releasing factors for are the hypothalamic corticotropin-releasing hormone (CRH) and arginine-vasopressin (AVP), which acts in synergy with $\mathrm{CRH}$ to potentiate hormone release. Glucocorticoids, secreted by the adrenal cortex, are the major physiological inhibitor. ACTH levels in plasma 
exhibit a circadian rhythm, with a peak in the early morning followed by a gradual decline during the night, and is controlled by clock neurons in the suprachiasmatic nucleus that synapse with CRH-producing neurons in the hypothalamic paraventricular nucleus. ACTH also exhibits faster, ultradian and hourly rhythms due to feedback between corticotrophs and adrenal cells. ${ }^{3}$

p0060 As its name implies, one of the major actions of ACTH is the promotion of growth of adrenal cortex cells. ACTH effects on these cells are also necessary for both basal and stress-induced secretion of glucocorticoids and aldosterone. Its half-life of $10 \mathrm{~min}$ allows for rapid adjustments of circulating levels of glucocorticoids. ACTH, CRH, and glucocorticoids are the main effector molecules of the hypothalamo-pituitary-adrenal (HPA) axis, the system that activates to help the organism adapt and cope with different stress cues (hypoglycemia, anesthesia, surgery, trauma, hemorrhage, infection, pyrogens) and psychiatric disorders like anxiety or depression.

p0065 Gonadotrophs constitute about $10-15 \%$ of the anterior pituitary endocrine cells and are localized throughout the pars distalis and most of the pars tuberalis of the anterior lobe. They form intimate contacts with lactotroph cells, with which they have extensive cell-tocell (paracrine) interactions. Gonadotrophs synthesize and release two hormones essential to the growth and function of the gonads in both genders (hence their common designation as gonadotropins): luteinizing hormone (LH) and follicle-stimulating hormone (FSH). Synthesis and release of both hormones are stimulated by gonadotropin-releasing hormone $(\mathrm{GnRH})$, which is secreted in a pulsatile manner by neurons that are dispersed within the mediobasal hypothalamus and preoptic areas. In addition, other hypothalamic factors such as gonadotropin-inhibiting hormone, vasopressin, substance $\mathrm{P}$, as well as feedback of gonadal factors (estrogens, progestogens, androgens and inhibin) contribute to the regulation of gonadotropins. The release of $\mathrm{LH}$ and $\mathrm{FSH}$ occurs in phase with pulses of $\mathrm{GnRH}$, with intervals that range from 30 to $60 \mathrm{~min}$ depending on the species and, for females, the stage of the ovarian cycle. During the ovarian cycle, the levels of LH and FSH in plasma correlate strongly with the gonadotropin content of the pituitary, and both are highest just before ovulation.

$\mathrm{LH}$, with a molecular weight of 28,000 , and $\mathrm{FSH}$, with a molecular weight of 33,000 , are glycoproteins with similar structures. Each is composed of the common pituitary hormone $\alpha$ subunit, also found in TSH, and a unique $\beta$ subunit that confers them hormonal specificity. The carbohydrate moiety of the latter subunit also enhances their half-life ( $1 \mathrm{~h}$ for $\mathrm{LH}$ and about $3 \mathrm{~h}$ for $\mathrm{FSH}$ ) and is critical for receptor binding and biological responses, and its modification allows considerable variation of the bioactivity of secreted LH and FSH molecules in different physiological conditions. LH stimulates the interstitial cell lines of male and female gonads (Leydig and thecal cells) mainly to secrete androgens (particularly testosterone), whereas FSH stimulates testicular Sertoli and ovarian granulosa cells to secrete estrogens (particularly estradiol) and a variety of protein products essential to spermatogenesis and oogenesis, respectively. During the initiation of the reproductive cycle of females, FSH acts on primary follicles to stimulate growth of the granulosa cells. Once the follicular phase is advanced and draws near to ovulation, LH also acts in female granulosa cells to promote progesterone production.

Lactotrophs make up about $15-25 \%$ of the adenohypophysial endocrine cell population and are a particularly non-homogeneous group of endocrine cells scattered throughout the anterior pituitary. A significant number are also found in the posterior medial portion of the gland. They synthesize and release prolactin (PRL), a 198 amino-acid protein that owes 
its name to its role in milk production during lactation in mammals. PRL has structural similarity and a comparable half-life $(20 \mathrm{~min})$ to GH. Like somatotrophs, lactotrophs inherently have high secretory activity due to their spontaneous electrical activity, though the former cells are not as active as lactotrophs in terms of their secretory activity. Thus, unlike all other anterior pituitary hormones, the physiological control of PRL is predominantly via tonic hypothalamic inhibition mediated by dopaminergic neurons located primarily in the arcuate nucleus. Therefore, a drop in the levels of

AU:4 dopamine (DA) in portal plasma often translates into an increase of the PRL-releasing activity of these cells. Hormone release by lactotrophs can also be stimulated by an extensive range of factors such as TRH, oxytocin, vasoactive intestinal peptide (VIP), angiotensin II, endothelin-1, serotonin and estrogens, but none of them have been established as a physiologically relevant PRL-releasing hormone. Like other trophic hormones, PRL secretion rises at night, and release occurs in episodic pulses.

p0080 In addition to its roles in the growth of alveolar breast cells and milk production, prolactin inhibits GnRH-induced release of gonadotropins in the anterior pituitary as well as the actions of gonadotropins on the gonads. This may be the mechanism by which it prevents ovulation in lactating women and normal sperm production in males. Indeed, PRL facili-

AU:5 tates the release of DA from the ME and thus acts in a negative feedback loop to inhibit its own secretion. Many other roles have been described for prolactin, including control of sexual behavior, induction of maternal behavior in pregnancy, and support of the corpora lutea during pregnancy and pseudopregnancy (in rodents). Similarly to ACTH, PRL release is stimulated by different stressor cues, including insulin-induced hypoglycemia, infection, surgery, anesthesia, and fear. Exercise and stimulation of the nipples both stimulate prolactin secretion, an effect that is thought to be mediated by oxytocin.

\section{DISEASES OF THE ANTERIOR PITUITARY}

Diseases of the pituitary can be divided into two major categories of pituitary disturbances, namely, hyperactivity (termed hyperpituitarism) and hypoactivity (hypopituitarism). ${ }^{4} \mathrm{We}$ focus on those that arise from disorders of the anterior pituitary. Because the function of the anterior pituitary is based on the specialized action (and interaction) of its different endocrine cells, the type of clinical response to each pituitary condition varies with the type of cell that is affected.

\section{Hypopituitarism}

With an annual estimated incidence (number of new cases per population in a given time period) of 4.2 per 100,000 and prevalence (proportion of the total number of cases to the total population) of 45.5 per 100,000, hypopituitarism might be caused by either an inability of the gland itself to produce hormones or an insufficient supply of hypothalamic-releasing hormones. It is causally associated with pituitary tumors $(61 \%)$, non-pituitary lesions (9\%), and non-cancerous causes (30\%), including perinatal insults, genetic causes, trauma and idiopathic cases. Often, mutations in genes encoding single hormones (or the receptor for their cell-specific hypothalamic releasing factor) result in single pituitary hormone deficiency. Unless successfully treated, hypopituitarism is chronic and lifelong, and in cases of shortage of ACTH or TSH it can cause life-threatening events and lead to increased mortality. If there is decreased secretion of most pituitary hormones, the term panhypopituitarism is used. 
s0040 p0095 ACTH DEFICIENCY This causes adrenal atrophy and ACTH-receptor downregulation, low blood pressure, low blood sugar level, fatigue, weight loss, and low tolerance for stress.

s0045 p0100 TSH DEFICIENCY Features of TSH deficit include underactive thyroid, fatigue, cold intolerance, weight gain, constipation, hair loss, dry skin and cognitive slowing.

s0050 p0105 LH, FSH DEFICIENCIES In premenopausal women, absent or infrequent menstrual cycles, infertility, vaginal dryness, dyspareunia (painful sexual intercourse), loss of libido, and loss of some female characteristics occur. In men, these deficiencies are associated with impotence, shriveling of testes, decreased sperm production, infertility, loss of libido, and loss of some male characteristics. In childhood, deficiencies result in delayed or missing onset of puberty.

s0055 p0110 GH DEFICIENCY The hallmarks of insufficient GH release are decreased muscle mass and strength, visceral obesity, fatigue, decreased quality of life, and impairment of attention and memory; there is stunted growth and dwarfism in children.

s0060 p0115 PRL DEFICIENCY Inability to produce breast milk after childbirth occurs in some women. However, elevated prolactin concentrations sometimes occur in hypopituitarism because of disruption of inhibitory signals by the hypothalamus, causing lactation, tenderness of the breast, and suppression of gonadotropins, leading to symptoms of hypogonadism.

\section{s0065 Hyperpituitarism}

p0120 Hyperpituitarism is the primary hypersecretion of pituitary hormones. It typically results from a pituitary tumor or adenoma, which represent from $10-25 \%$ of all intracranial neoplasms. Most pituitary adenomas are benign, functional, and secrete a hormone that produces clear symptoms characteristic of their condition. The four most common types of adenoma-related hyperpituitarism are prolactinoma, corticotropinoma (Cushing's disease), somatotropinoma (gigantism), and null cell adenomas that do not secrete hormones. Since the enlargement of the anterior pituitary gland can damage the optic nerves and compress the hypothalamus, some of its common symptoms are headache, loss of side or peripheral vision, and hyposecretion of neighboring anterior pituitary hormones. Clinically active pituitary adenomas affect approximately one in 1000 of the general population but are rare in children.

PROLACTINOMA This is an adenoma of lactotroph cells and the most common type of pituitary tumor ( $30 \%$ of pituitary adenomas). In women, high blood levels of prolactin often cause changes in menstruation (periods may become irregular or disappear) and those who are not pregnant or nursing may begin producing breast milk (galactorrhea). Because of the hyperprolactinemia-induced inhibition of the gonadotropin axis, women with hyperprolactinemia also exhibit symptoms of gonadotropin deficit, such as loss of libido, dyspareunia, vaginal dryness and hypogonadism. In males, the most common symptom of prolactinoma is impotence, loss of libido, hypogonadism, oligospermia, and diminished ejaculate volume.

CORTICOTROPINOMA Also known as Cushing's disease, this is a tumor of corticotroph cells that accounts for $20 \%$ of pituitary adenomas. The symptoms reflect the presence of excess cortisol or ACTH and include weight gain, high blood pressure, poor short-term memory, irritability, extra fat around the neck, a round and ruddy face, fatigue, and poor concentration. Women also exhibit menstrual irregularity and hirsutism (abnormal hair growth). 
s0090 p0135 SOMATOTROPINOMA This is a tumor of somatotroph cells that represents $15 \%$ of pituitary adenomas. The resulting hypersecretion of GH in adults causes acromegaly (an overgrowth of the terminal parts of the skeleton such as the nose, mandible, hands and feet). When it presents in children and adolescents it causes gigantism; disruption of sexual maturation is common, either because of hormone hypersecretion or because of manifestations caused by compression of hypothalamic connections by the adenoma.

s0095 p0140 NULL CELL ADENOMAS These are dysfunctional tumors that account for $25 \%$ of pituitary adenomas. Because they do not secrete hormones, symptoms are restricted to headache, increased intracranial pressure and visual field defects.

s0100 p0145 GONADOTROPHIC ADENOMAS These are tumors of gonadotroph cells that account for $10 \%$ of pituitary adenomas. Although functional, they are usually clinically silent.

s0105 p0150 THYROTROPHIC ADENOMAS These are rare (less than 1\%) but have the particular characteristic of being plurihormonal, since they produce the common glycoprotein $\alpha$-subunit, prolactin, and the specific $\beta$-subunits of LH and FSH.

\section{PHENOTYPIC PROFILE OF ANTERIOR PITUITARY CELL TYPES: DIFFERENT, YET SOMEWHAT SIMILAR}

p0155 The anterior pituitary endocrine cell types are classically defined on the basis of the expression of a specific hormone and its corresponding mRNA, and this is determined by various lineage-specific transcription factors. ${ }^{5}$ Although two-thirds of the population of each anterior pituitary cell type exclusively express their respective hormone at both mRNA and protein levels, the remainder coexpress the mRNAs of two to four different hormones. ${ }^{6}$ For example, a GH cell can also express the mRNAs of PRL, TSH- $\beta$, LH- $\beta$ and POMC. In addition, a significant fraction of the nonhormone producing cells contain multiple hormone mRNAs that fail to be translated into the mature protein. Thus, at the mRNA level, the various anterior pituitary hormones are shared by a fraction of cells that express multilineage phenotypes. These multiple mRNA-containing (or polyhormonal) cells are thought to be progenitor cells or "reserve" cells that upon appropriate signals will terminally differentiate depending on developmental and/or physiological needs. The origin and biological relevance of these cells are currently a matter of intense investigation and debate.

The current paradigm for hypothalamic control of anterior pituitary hormone secretion holds that each hypothalamic-releasing hormone modulates the release of a single pituitary hormone by acting on a single cell type. However, when attempts were made to characterize cell phenotypes on the basis of whether their intracellular calcium concentration $\left(\left[\mathrm{Ca}^{2+}\right]_{i}\right)$ responded to a specific hypothalamic releasing hormone, many cells were found to respond to two or more of these agents. Furthermore, hormone release assays in single living cells revealed that multiresponsiveness also exists with respect to hormone release. Such "paradoxical" hormone release by a noncorrresponding hypothalamic releasing hormone had, in fact, been observed in a number of in vitro and in vivo studies using normal and pathological cells. Indeed, a growing body of evidence suggests that $30-40 \%$ of normal pituitary cells remain in a multipotential state, able to respond to as many as four different hypothalamic secretagogues. ${ }^{7}$ In some pituitary adenomas, these multi-responsive cells can constitute up to $80 \%$ of the endocrine cells. Moreover, much like the 
polyhormonal cells described above, multiresponsive cells are not restricted to any particular cell type. Thus, different cell types can also share receptors to allegedly cell-specific hypothalamic neurohormones. In fact, the mRNA of the receptor for the classic hypothalamic GH inhibitory hormone, somatostatin, is found among all five major cell types of the anterior pituitary. The type $1 \mathrm{CRH}$ receptor (CRH-R1) is not exclusively expressed by corticotrophs; subsets of lactotrophs, gonadotrophs and thyrotrophs also express it in different degrees. It has also been shown that about 35\% of somatotrophs bind biotinylated GnRH, the stimulating hormone for gonadotrophs. It has been hypothesized that estrogens and possibly activin stimulate the expression of $\mathrm{GnRH}$ receptors in pre-existing $\mathrm{GH}$ cells at midcycle, rendering them capable of fully responding as a gonadotroph to help support the GnRHmediated proestrus surge of $\mathrm{LH}$ and $\mathrm{FSH}$ release. Additionally, retention of GHRH receptors would allow supporting the GH needs of the reproductive system at this time. ${ }^{8}$

p0165 Whether these multi-responsive cells derive from an independent multipotential subset or from pre-existing differentiated cells (termed transdifferentiation), they provide a cellular basis for anterior pituitary plasticity. Two observations are consistent with this. The first one is that multi-responsive cells are maximally abundant at puberty, a time signed by huge endocrine and physiological transformation. Secondly, multifunctional cells seem to be more abundant in females than in males, suggesting not only that the female pituitary may be more plastic than the male pituitary, but also that the hormonal changes associated with the female reproductive cycle may promote transdifferentiation.

p0170 Unstimulated anterior pituitary cells can also be classified by their biophysical and biochemical properties, more specifically, on their patterns of electrical activity and intracellular
$\mathrm{Ca}^{2+}$ dynamics. ${ }^{9,10}$ A general feature of cultured anterior pituitary cells is that their membrane potential $\left(\mathrm{V}_{\mathrm{m}}\right)$ oscillates between potentials of -60 to $-50 \mathrm{mV}$. When $\mathrm{V}_{\mathrm{m}}$ reaches the threshold level, pituitary cells fire action potentials (APs), a feature called spontaneous electrical activity and is observed in $15-80 \%$ of the cells, depending on the cell type and of cultural and/or recording conditions. The firing of APs causes transients of intracellular $\mathrm{Ca}^{2+}$ concentration $\left(\left[\mathrm{Ca}^{2+}\right]_{\mathrm{i}}\right)$ that in turn reflect the pattern of electrical activity. Two patterns of electrical activity are typically observed in anterior pituitary cells. The first, termed axonal-type AP spiking, is typically found in gonadotrophs, ${ }^{11}$ thyrotrophs, ${ }^{12}$ and largely in corticotrophs, ${ }^{13}$ and is characterized by sharp single APs that are short in duration (less than $100 \mathrm{~ms}$ ), with spike frequencies of about $0.7 \mathrm{~Hz}$ and amplitudes of more than $60 \mathrm{mV}$. Axonal-type AP spiking is associated with small-amplitude $\left[\mathrm{Ca}^{2+}\right]_{i}$ transients that range from $20 \mathrm{nM}$ to $70 \mathrm{nM}$ and low basal hormonal release in these cells. The second pattern, termed pseudo-plateau bursting and characteristic of cultured somatotrophs ${ }^{14}$ and lactotrophs, ${ }^{15}$ exhibits broader $\mathrm{V}_{\mathrm{m}}$ oscillations in the form of a depolarizing plateau with superimposed bursts of small amplitude APs that usually do not reach $0 \mathrm{mV}$. Such bursts have a longer duration (several seconds) than gonadotroph APs, so that the burst frequency is significantly lower (about $0.3 \mathrm{~Hz}$ ), and result in an oscillatory increase in $\left[\mathrm{Ca}^{2+}\right]_{i}$ of high amplitude that ranges from 0.3 to $1.2 \mu \mathrm{M}$ and is sufficient to maintain high and steady hormonal (GH and prolactin) release. Although the typical patterns of spontaneous electrical activity are useful for the identification of the different cell populations of the anterior pituitary, they should not be used as the sole criteria, since the electrical activity of these cells often experience spontaneous reversible transitions between the two modes. 
s0115

\section{HETEROGENEITY WITHIN ANTERIOR PITUITARY CELL TYPES: SIMILAR, YET SOMEWHAT DIFFERENT}

p0175 Although different cell types have similarities, it is also apparent that similar cells (that is, cells within a cell type population) may present striking differences. It has been long recognized that each of the different types of anterior pituitary cells are functionally heterogeneous, which is thought to be related to structural heterogeneity. One of the best known examples is found among gonadotrophs, ${ }^{16,17}$ which are heterogeneous in size (cell area ranging from $30-170 \mu \mathrm{m}^{2}$ ), morphology (large rounded, small oval and angular stellate cells), physical density (allowing their separation using sedimentation techniques at unit gravity), ultrastructural characteristics (type I gonadotrophs characterized by dilated rough ER (RER) cisternae and secretory granules of $200 \mathrm{~nm}$ and $300-700 \mathrm{~nm}$ in diameter, type II gonadotrophs by flattened RER cisternae and 200-250 nm secretory granules, type III gonadotrophs by a stellate shape and secretory granules of $220-250 \mathrm{~nm}$ ), hormone content (small gonadotrophs seem to store only one of the gonadotropins, whereas most of the larger cells either store both LH and FSH, or FSH alone) and responsiveness (variable capacity to bind and respond to GnRH). These gonadotroph subpopulations may account for the differential regulation of LH and FSH secretion in vivo.

p0180 The other anterior pituitary cell types exhibit heterogeneity of these cellular features as well. In the porcine pituitary, somatotrophs comprise two morphologically distinct subpopulations of low- (LD) and high-density (HD) cells, separable by Percoll gradient, that respond differently to hypothalamic regulators. In LD somatotrophs, somatostatin inhibits GHRH-induced GH secretion, whereas somatostatin alone stimulates $\mathrm{GH}$ release from HD somatotrophs.
Functional heterogeneity of corticotrophs displays striking sexual dimorphism. In males, the corticotrophs are of the orthodox phenotype, that is, monohormonal (storing only ACTH) and monoreceptorial (responding only to $\mathrm{CRH}$ ). Their female counterparts are made of about equal parts of orthodox and multifunctional cells. Sexual dimorphism and functional heterogeneity are even more striking in thyrotrophs, which are mostly polyhormonal in both genders, but only female thyrotrophs co-store $\mathrm{GH}$ and/or ACTH in addition to prolactin and/or LH. Among lactotrophs, three morphological types in rodents have been defined by electron microscopy. Type I "classical" lactotrophs contain large irregular-shaped electrondense secretory granules (diameter $300-700 \mathrm{~nm}$ ), type II cells contain numerous medium sized spherical electron-dense granules (diameter $100-250 \mathrm{~nm}$ ) and type III cells contain small $(<100 \mathrm{~nm})$ spherical granules. Though thought to represent different stages of cell maturity, these morphologically-defined lactotroph subpopulations have functional differences, as these subtypes are differentially sensitive to hypothalamic and local regulators of prolactin secretion. ${ }^{18}$

Several substates of a particular pattern of electrical activity can be found within a given anterior pituitary cell type. In somatotrophs, the burst period of somatotrophs ranges from 2 to $10 \mathrm{~s}$, with longer active phase duration associated with the slower bursting, which results in increased $\mathrm{Ca}^{2+}$ influx through voltage-gated $\mathrm{Ca}^{2+}$ channels (VGCC) and higher amplitude $\mathrm{Ca}^{2+}$ oscillations. An explanation of the heterogeneity of the active phase duration has been recently provided. ${ }^{14,19}$

Lactotrophs also display considerable variability in their spontaneous and receptorcontrolled patterns of electrical activity and $\mathrm{Ca}^{2+}$ dynamics. The authors have recently addressed the heterogeneity in the $\left[\mathrm{Ca}^{2+}\right]_{\mathrm{i}}$ responses of lactotrophs to TRH..$^{20}$ Responses were evaluated in 
the absence of extracellular $\mathrm{Ca}^{2+}$ to prevent $\mathrm{Ca}^{2+}$ influx during the agonist challenge and remove one potential source of heterogeneity. Figure 2.1A shows thirteen $\mathrm{Ca}^{2+}$ traces from individual lactotrophs responding to the same TRH application, exhibiting considerable variability. In contrast, Figure 2.1B-E shows traces from four different lactotroph cells subjected to two consecutive TRH applications. In each cell, the response to the second TRH pulse was very similar to that of the first pulse. Thus, during the time course of the observations, heterogeneity in the $\mathrm{Ca}^{2+}$ response to TRH could be observed among lactotroph cells, with uniformity of response within single cells to multiple TRH applications. Of the many potential variables that could result in the observed heterogeneity of the $\mathrm{Ca}^{2+}$ responses to TRH, the authors have found that variability in the rate of $\mathrm{Ca}^{2+}$ extrusion through the plasma membrane $\left(\mathrm{k}_{\mathrm{PMCA}}\right)$ largely accounts for it. Since TRH may modulate the activity of the plasma membrane $\mathrm{Ca}^{2+}$ adenosine triphosphate (ATP)ase pump, it might also contribute to the observed $\mathrm{k}_{\mathrm{PMCA}}$ heterogeneity.
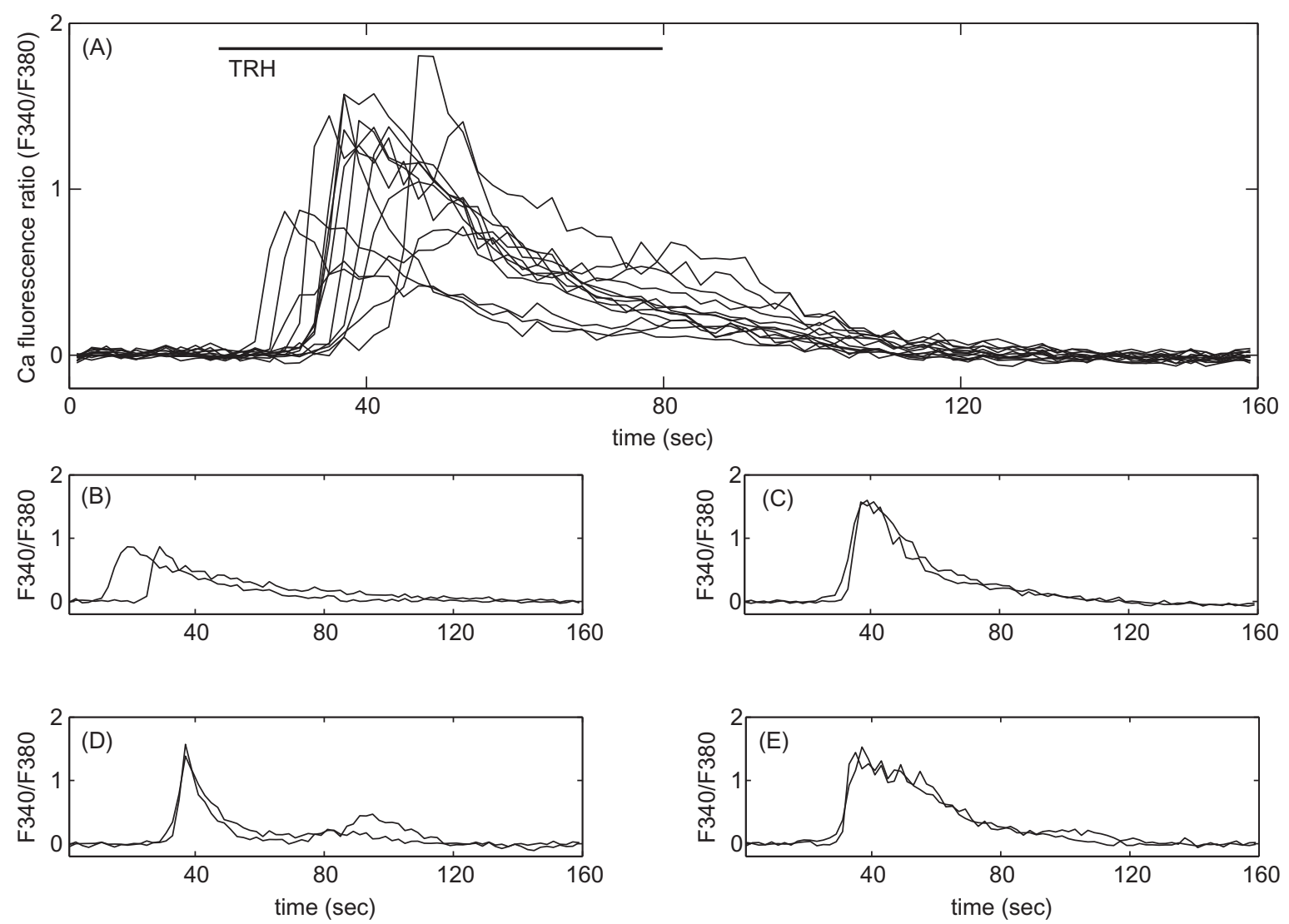

f0010 FIGURE 2.1 Heterogeneity of the $\mathrm{Ca}^{2+}$ response to thyrotropin-releasing hormone (TRH) in pituitary lactotrophs. In all panels, the $x$-axis shows time in seconds, and the $y$-axis shows the $\mathrm{Ca}^{2+}$ fluorescence ratio $\left(\mathrm{F}_{340} / \mathrm{F}_{380}\right)$. (A) Thirteen individual $\mathrm{Ca}^{2+}$ traces from the same experiment. Extensive variation exists in the peak, area, latency of response and decay rate. (B-E) Examples of single cell $\mathrm{Ca}^{2+}$ traces from the same experiment showing very similar responses to two successive challenges of TRH, $30 \mathrm{~min}$ apart. Original figure published in $\mathrm{ref}^{20}$. 
We also found that variability in the $\left[\mathrm{Ca}^{2+}\right]$ in the endoplasmic reticulum $\left(\left[\mathrm{Ca}^{2+}\right]_{\mathrm{ER}}\right)$ is likely a key element of heterogeneity. In addition, our results did not show a positive correlation between the peak and decay rate of the intracellular $\mathrm{Ca}^{2+}$ transients, suggesting that variations in the $\mathrm{G}_{\mathrm{q}} / \mathrm{IP}_{3}$ signaling pathway are not the main source of heterogeneity.

\section{s0120 PATTERNS OF ANTERIOR PITUITARY CELL SIGNALING AND SECRETION}

\section{s0125 Molecular Mechanisms Underlying Excitability and Basal Secretion}

p0195 In excitable anterior pituitary cells, the resting membrane potential is controlled by classical inward rectifier $\mathrm{K}^{+}\left(\mathrm{K}_{\mathrm{ir}}\right)$, ether-a-go-go-related gene (ERG) and TWIK-related (TREK-1) $\mathrm{K}^{+}$conducting channels. Because the $\mathrm{V}_{\mathrm{m}}$ of anterior pituitary cells ranges between -50 to $-60 \mathrm{mV}$, other depolarizing conductances must contribute to maintaining the resting potential. Recent findings indicate that tetrodotoxin (TTX)-insensitive $\mathrm{Na}^{+}$-conducting channels, along with lowvoltage-activated transient (T)-type voltage-gated $\mathrm{Ca}^{2+}$ channels, not only participate in the control of the resting potential but also act as pacemaking currents underlying the spontaneous activity frequently observed in isolated cells. ${ }^{10}$ In physiological (in vivo) conditions, TTX-sensitive voltagegated $\mathrm{Na}^{+}$channels may play a role in the production of action potentials in hyperpolarized cells. However, high voltage-activated, dihydropyridine-sensitive long lasting (L)-type $\mathrm{Ca}^{2+}$ channels account for the bulk of the conductance during spike depolarization as removal of extracellular $\mathrm{Ca}^{2+}$ and addition of VGCC blockers abolish electrical activity in the majority of the endocrine pituitary cells without affecting their resting membrane potential. Finally, the concerted activity of delayed-rectifying $\mathrm{K}^{+}$channels with both BK (large conductance) and SK (small conductance) types of $\mathrm{Ca}^{2+}$-activated $\mathrm{K}^{+}$ channels repolarize the $\mathrm{V}_{\mathrm{m}}$ during the downstroke of an AP. In bursting cells, BK channels are also functionally important.

The distinctive patterns of electrical activity p0200 and $\mathrm{Ca}^{2+}$ dynamics exhibited by different types of pituitary cells are thought to arise from differences in the expression levels of ion channels such as those involved in bursting and repolarization. For example, BK channels are expressed at higher levels in somatotrophs and lactotrophs (which exhibit pseudo-plateau bursting activity) than in gonadotrophs (which display continuous, axonal-type AP spiking). ${ }^{21}$ This correlation between BK channel expression levels and pattern of electrical activity suggests that larger BK conductance favors the generation of bursting activity and global $\mathrm{Ca}^{2+}$ signals. Indeed, blockade of BK channels in pituitary somatotrophs can switch the activity pattern of these cells from bursting to spiking, greatly reducing the amplitude of $\left[\mathrm{Ca}^{2+}\right]_{i}$ oscillations. ${ }^{22}$ In other words, it is possible to convert the firing phenotype of somatotrophs to that of gonadotrophs by reducing their BK conductance. The reciprocal conversion is also true: addition of an artificial BK conductance to cultured gonadotrophs through the dynamic clamp technique changes their activity pattern from spiking to bursting. ${ }^{19}$ Mathematical modeling predicted that the activation time constant of the BK conductance is important. BK activation must be fast to promote bursting; if too slow, then the BK current does not promote bursting and instead takes on its traditional inhibitory role on electrical activity. ${ }^{19}$ Faster BK activation kinetics limit spike amplitude, preventing full activation of the repolarizing delayed rectifier $\mathrm{K}^{+}$current, so membrane potential weakly oscillates around a depolarized level ${ }^{14,22,23}$ before falling back toward rest, which results in bursting, increased $\mathrm{Ca}^{2+}$ influx and global $\mathrm{Ca}^{2+}$ signals. 
p0205 Unlike classical neuronal synapses, neuroendocrine and endocrine cells require sustained depolarization to trigger the exocytotic pathway. In anterior pituitary cells, VGCC are open only briefly during the short time of a single $\mathrm{AP}$, and the elevated $\left[\mathrm{Ca}^{2+}\right]_{\mathrm{i}}$ is localized to the nanodomains that form at the inner mouths of open channels. With longer durations and smaller burst amplitudes, VGCC stay open much longer and significant $\mathrm{Ca}^{2+}$ influx ensues, resulting in the summation of individual $\left[\mathrm{Ca}^{2+}\right]_{i}$ nanodomains that generate a global $\mathrm{Ca}^{2+}$ signal. Therefore, differences in the ability of spontaneous firing patterns to generate global $\left[\mathrm{Ca}^{2+}\right]_{\mathrm{i}}$ signals will determine their basal secretory activity For example, the basal release of GH and prolactin is much higher than that of LH, which is consistent with the pseudo-plateau bursting activity of somatotrophs and lactotrophs that result in high-amplitude (global) $\left[\mathrm{Ca}^{2+}\right]_{\mathrm{i}}$ signals and the short-duration APs of gonadotrophs that evoke low-amplitude (local) $\left[\mathrm{Ca}^{2+}\right]_{\mathrm{i}}$ signals.

\section{s0130 Receptor-Modulated Hormone Release AU:8 and Voltage-Gated $\mathrm{Ca}^{2+}$ Influx through cAMP-Dependent Pathways}

p0210 A number of hypothalamic neurohormones and peripheral hormones control AP-driven $\mathrm{Ca}^{2+}$ dynamics and $\mathrm{Ca}^{2+}$-dependent hormone release in anterior pituitary cells through modulation of cAMP-dependent pathways. These bind and activate a $\mathrm{G}$ protein-coupled receptor (GPCR) to modulate the basal activity of adenylyl cyclase $(\mathrm{AC}$, the enzyme responsible for synthesizing (AMP) and, in turn, $\mathrm{Ca}^{2+}$ entry. Those that promote AP-driven $\mathrm{Ca}^{2+}$ dynamics and $\mathrm{Ca}^{2+}$ dependent secretion bind to GPCRs coupled to the stimulatory class of $G$ proteins $\left(\mathrm{G}_{\mathrm{s}}\right)$ to increase AC activity through the activation of the $\alpha$ subunit of the $G_{s}$ protein, whereas those that reduce $\mathrm{Ca}^{2+}$ signaling and secretion bind to GPCRs coupled to the inhibitory class of $G$ proteins $\left(G_{i / o}\right)$ to decrease AC activity.
The stimulatory $\mathrm{G}_{\mathrm{s}}$-signaling pathway is trig- p0215 gered by CRH receptors in corticotrophs, GHRH receptors in somatotrophs and VIP/pituitary adenylate cyclase-activating polypeptide (PACAP) receptors in lactotrophs, somatotrophs and FS cells. Activation of the $\mathrm{G}_{\mathrm{s}}$-operated GPCRs causes plasma membrane depolarization, increased electrical activity and $\mathrm{Ca}^{2+}$ entry. The type of $\left[\mathrm{Ca}^{2+}\right]_{I}$ response is a plateau elevation of $\left[\mathrm{Ca}^{2+}\right]_{\mathrm{I}}$ or an increase in the frequency and/or amplitude of $\left[\mathrm{Ca}^{2+}\right]_{I}$ transients as elevated cAMP levels promote, directly or indirectly, electrical activity and voltage-gated $\mathrm{Ca}^{2+}$ influx (VGCI). The direct pathway consists of the activation of a background $\mathrm{Na}^{+}$conductance that results upon binding of cAMP to hyperpolarization-activated and cyclic nucleotide-regulated ( $\mathrm{HCN})$ channels. $\mathrm{HCN}$ channels are expressed in somatotrophs, ${ }^{24}$ lactotrophs, ${ }^{25}$ gonadotrophs and thyrotrophs, ${ }^{12}$ and probably corticotrophs. ${ }^{26}$ Because they are nonselective cation channels, they are likely to play a role in the initiation of the pacemaker depolarization. The indirect pathway consists of the activation of cAMP-dependent kinases (PKAs) that induce phosphorylation-mediated modulation of the function of several plasma membrane ion channels. In corticotrophs, CRH-induced PKA activation inhibits Kir channels to promote slow depolarization and enhanced excitability. In somatotrophs, GHRH-stimulated PKAmediated phosphorylation results in the opening of not only T-type and L-type $\mathrm{Ca}^{2+}$ channels, but also TTX-insensitive voltage-gated $\mathrm{Na}^{+}$channels, leading to the upstroke of a voltage spike.

The inhibitory $G_{i} / o^{-}$signaling pathway is trig- p0220 gered in lactotrophs by dopamine D2 and endothelin-1 ETA receptors, and in both lactotrophs and somatotrophs by somatostatin sst1, sst 2 and sst 5 receptors. Other receptors linked to this pathway and expressed by anterior pituitary cells include those for adenosine, $\gamma$-aminobutyric acid (GABA), serotonin, melatonin and neuropeptide $Y$. Activation of this pathway opposes the actions mediated by the $\mathrm{G}_{\mathrm{s}}{ }^{-}$ 
signaling pathway resulting in membrane hyperpolarization, silencing of electrical activity and inhibition of $\mathrm{Ca}^{2+}$ entry and $\mathrm{Ca}^{2+}$-dependent hormone secretion. $\mathrm{G}_{\mathrm{i} / \mathrm{o}}$-mediated inhibitory actions, which can be irreversibly blocked by application of pertussis toxin, comprise two major signaling branches. The first one stems from the $G_{i / o} \alpha$-subunit-mediated inhibition of AC activity, downregulating all cAMPstimulated effects on electrical activity, $\mathrm{Ca}^{2+}$ entry and secretion. The second is due to the activation of $\mathrm{G}_{\mathrm{i} / \mathrm{o}} \beta \gamma$ dimers that activate Kir3 (also known as $G$ protein-gated inwardly rectifying $\mathrm{K}^{+}$channels, GIRK) and inhibit L-type $\mathrm{Ca}^{2+}$ channels in a cAMP/PKA-independent fashion, leading to hyperpolarization and cessation of AP firing. Interestingly, three of the four mammalian Kir3 channels are specifically induced by estradiol in lactotrophs in proestrus, ${ }^{27}$ underlying dopamine effects that are only observed in this stage of the cycle: strong Kir conductance and robust hyperpolarization, the latter playing a critical role in the prolactin secretory rebound that follows dopamine withdrawal. ${ }^{28}$ A novel mechanism has been recently described for endothelin ETA and dopamine D2 receptors in lactotrophs. In addition to the $G_{i / o}$ class of $G$ proteins, these receptors couple to $G_{z}$ proteins, a subfamily of $G_{i / o}$ proteins that are insensitive to pertussis toxin. Activation of the $\alpha$ subunit and $\beta \gamma$ dimers of $G_{z}$ by these receptors potently block VGCI and prolactin release by inhibiting $\mathrm{AC}$ activity and the exocytotic machinery responsible for secretion. $^{29,30}$

\section{s0135 Receptor-Modulated Hormone Release through $\mathrm{Ca}^{2+}$-Mobilizing Pathways}

p0225 All anterior pituitary cell types express $\mathrm{Ca}^{2+}$-mobilizing GPCRs. Examples in gonadotrophs include the receptors for $\mathrm{GnRH}$, endothelins, PACAP and substance P; in lactotrophs such receptors include those for acetylcholine, angiotensin II, TRH, oxytocin, ATP, endothelin, serotonin, galanin and substance P; somatotrophs express ghrelin and endothelin receptors; in corticotrophs, AVP and norepinephrine receptors; and in thyrotrophs, TRH (the main thyrotroph secretagogues) and endothelin elicit $\mathrm{Ca}^{2+}$ mobilization. When activated, these $\mathrm{Ca}^{2+}$-mobilizing GPCRs couple to the $G_{q}$ protein class of heterotrimeric $G$ proteins, eliciting the dissociation of the $\alpha_{q}$ subunit that triggers phospholipase C-mediated phosphoinositide hydrolysis resulting in the formation of inositol 1,4,5 triphosphate $\left(\mathrm{IP}_{3}\right)$ and diacylglycerol (DAG) (Figure 2.2). $\mathrm{IP}_{3}$ binds to $\mathrm{IP}_{3}$ receptors expressed in the membrane of the endoplasmic reticulum (ER), the primary storehouse of $\mathrm{Ca}^{2+}$ in most cells, causing a mobilization of $\mathrm{Ca}^{2+}$ out of this compartment and leading to a large and fast increase of $\left[\mathrm{Ca}^{2+}\right]_{\mathrm{I}}{ }^{31}$

Two different $\mathrm{Ca}^{2+}$ signaling patterns can be observed after the initial $\left[\mathrm{Ca}^{2+}\right]_{I}$ spike. The first one, termed "biphasic," is a non-oscillatory pattern found in lactotrophs, somatotrophs and thyrotrophs where the transient $\left[\mathrm{Ca}^{2+}\right]_{I}$ spike is followed by a slow decline to a plateau level that is above basal. However, some cells exhibit "monophasic" responses where only the spike or the plateau is observed. A key condition of the biphasic $\mathrm{Ca}^{2+}$ response is that the $\mathrm{IP}_{3} \mathrm{Rs}$ are opened continuously throughout the time of agonist application. The microdomain of $\mathrm{Ca}^{2+}$ that forms near the mouth of the $\mathrm{IP}_{3}$ receptor during the $\mathrm{Ca}^{2+}$ spike is high enough to trigger exocytosis. Furthermore, the transient $\left[\mathrm{Ca}^{2+}\right]_{I}$ surge activates the small-conductance $\mathrm{Ca}^{2+}$-activated $\mathrm{K}^{+}$ channels (SK) and hyperpolarizes the plasma membrane, terminating any previous electrical activity. ${ }^{10,32}$ As the $\mathrm{Ca}^{2+}$ is removed from the cytosol, by means of plasma membrane ATPase pumps and $\mathrm{Na}^{+} / \mathrm{Ca}^{2+}$ exchangers as well as sarco-endoplasmic reticulum $\mathrm{Ca}^{2+}$ ATPase (SERCA) pumps, the SK channels close and the membrane depolarizes. Depletion of the ER $\mathrm{Ca}^{2+}$ store also provides a signal for the activation of transient receptor potential eation channels (TRPCs) and other store-operated $\mathrm{Ca}^{2+}$ channels 
(A) Gq/11-coupled GPCRs

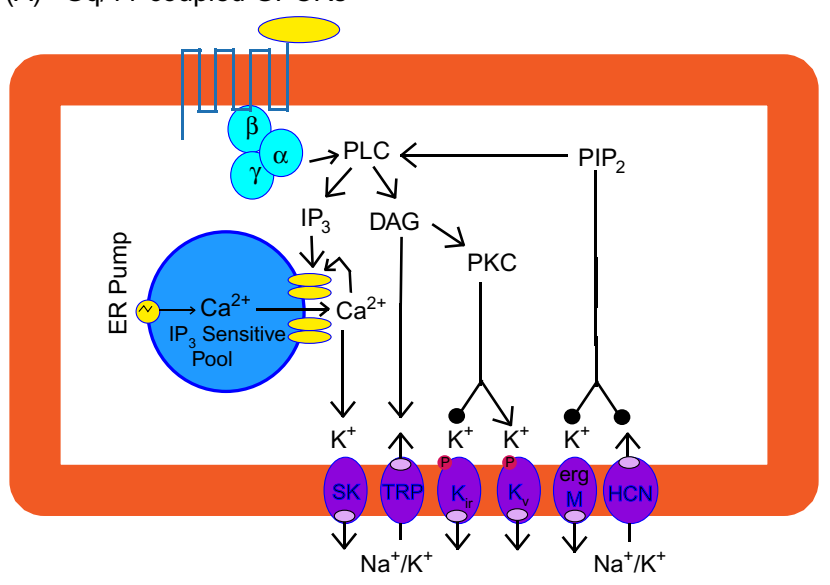

(B)
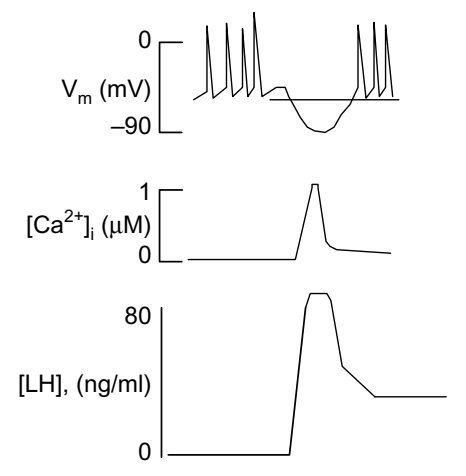

f0015 FIGURE 2.2 (A) Mechanism of receptor-induced electrical activity and $\mathrm{Ca}^{2+}$ signaling by activated $\mathrm{G}_{\mathrm{q}}$ - coupled, $\mathrm{Ca}^{2+}$ mobilizing receptors. (B) Schematic representation of a biphasic response typically observed in gonadotrophs upon GnRH-induced stimulation of electrical activity (top), cytosolic $\mathrm{Ca}^{2+}$ (middle) and hormone secretion (bottom). The generation of a biphasic response reflects the tonic activation of $\mathrm{IP}_{3}$ receptors (see text for details).

(SOCs) important for depolarization. Diacylglycerol may directly activate TRP channels or may inhibit Kir currents through protein kinase C (PKC)-dependent phosphorylation (Figure 2.2). In addition to these events, downregulation of an M/ERG channel via PLCmediated $\mathrm{PiP}_{2}$ depletion leads to a sustained depolarization phase that activates voltage-gated $\mathrm{Ca}^{2+}$ channels, further depolarizing the cell and initiating single spiking or bursting (Figure 2.2). The resulting $\mathrm{Ca}^{2+}$ entry refills the ER $\mathrm{Ca}^{2+}$ store, enabling continued $\mathrm{Ca}^{2+}$ signaling.

p0235 In contrast to the biphasic $\mathrm{Ca}^{2+}$ response described above, GnRH-stimulated gonadotrophs and norepinephrine-stimulated corticotrophs engage in an oscillatory $\mathrm{Ca}^{2+}$ response after the initial transient of $\left[\mathrm{Ca}^{2+}\right]_{\mathrm{I}}$. Interestingly, oscillations in $\mathrm{IP}_{3}$ are not required to generate oscillatory $\mathrm{Ca}^{2+}$ release in gonadotrophs. The $\mathrm{IP}_{3}$ receptor itself is the source of the oscillation, since it is activated by cytosolic $\mathrm{Ca}^{2+}$ on a fast time scale and inhibited on a longer time scale. The delayed inhibition of the channel produces oscillations. ${ }^{33}$ This is a true ER-mediated oscillation, as it can be produced even when the membrane potential is clamped at a voltage sufficiently high to allow $\mathrm{Ca}^{2+}$ influx that refills the ER between each bout of $\mathrm{Ca}^{2+}$ release. ${ }^{34}$ In the unclamped cell, a key feature of the oscillatory response is the antiphasic pattern of electrical activity and $\mathrm{Ca}^{2+}$ release due to the SK channel-mediated inhibitory action of each $\mathrm{Ca}^{2+}$ pulse on the plasma membrane (see $\operatorname{ref}^{10}$ ). Once $\left[\mathrm{Ca}^{2+}\right]_{\mathrm{I}}$ returns to a low level following the $\mathrm{Ca}^{2+}$ pulse, firing resumes. The electrical activity and secretion are out of phase; the former serves to refill the $\mathrm{ER} \mathrm{Ca}^{2+}$ store that periodically releases $\mathrm{Ca}^{2+}$ and evokes secretion during sustained stimulation.

\section{PARACRINE (LOCAL) REGULATION AND \\ INTERCELLULAR SIGNALING WITHIN THE ANTERIOR PITUITARY}

More than 100 bioactive substances are expressed by cells of the anterior pituitary and can act within the gland through specific 
receptors, allowing these messengers to exert a local regulatory function during specific physiological states. Depending on the cellular location of both the signaling molecule and its respective receptor, such messengers may act either on the same cell (autocrine control), an adjacent cell (juxtacrine control), a neighboring cell (paracrine control) or even within the same cell where the signaling molecule is produced without being secreted (intracrine control). Such interactions are highly contextdependent and constitute the cellular basis of locally controlled anterior pituitary plasticity. In general, they either promote or inhibit hormone release and cell proliferation, and are switched on/off when hormonal outputs need to be adapted to changing demands of the organism, such as during mating, pregnancy, lactation, stress, inflammation, immune responses, starvation and circadian rhythms. We will briefly highlight physiologically relevant paracrine and autocrine interactions that have been substantiated with reasonable evidence. Comprehensive reviews on this topic have been recently published. ${ }^{17,35}$

p0245 Well-established autocrine mechanisms in lactotrophs include the stimulatory loops of VIP, galanin and TGF- $\alpha$ as well as the inhibitory loops of TGF- $\beta 1$ and endothelins. In gonadotrophs, the autocrine loop made up by activin B (stimulatory) and follistatin (inhibitory), along with that of inhibin (inhibitory), constitute one of the fundamental mechanisms for selective regulation of FSH expression and secretion, as changes in GnRH pulse frequency cause changes of expression of these three modulators that in turn change the FSH:LH ratio. ${ }^{36}$ Nitric oxide (NO) is also an important autocrine/paracrine modulator of gonadotrophs as both these cells and FS cells express nitric oxide synthase (NOS). NO may play both inhibitory and stimulatory roles, and this might depend on the cellular source of $\mathrm{NO}$, as NO from FS cells seems to inhibit GnRHstimulated LH release whereas gonadotroph
NO stimulates basal LH and FSH secretion. PACAP also plays autocrine roles in gonadotrophs where it is specifically expressed in proestrus to stimulate LH release through interaction with the gonadotroph NO system and GnRH signaling pathways. The purine ATP has been shown to be costored with hormones in secretory granules and cosecreted in all endocrine cell types of the anterior pituitary, ${ }^{37}$ but autocrine roles have only been consistently shown in gonadotrophs where it potently stimulates basal LH release. In corticotrophs, expression of CRH and AVP (which has also been detected in all endocrine cell types except somatotrophs) and their receptors underlies an autocrine mechanism by which $\mathrm{CRH}$ and AVP may contribute to the wellestablished potentiation of ACTH release by hypothalamic CRH and AVP. In somatotrophs, ghrelin has been shown to sensitize the cell to GHRH at early postnatal age (and possibly at puberty). ${ }^{38}$ In thyrotrophs, stimulatory and inhibitory autocrine roles for leptin and neuromedin B, respectively, have been shown to be important in the control of TSH secretion during adaptation to nutritional status.

The majority of the paracrine interactions reported so far are those of gonadotrophs with different endocrine cell types of the anterior pituitary, particularly lactotrophs, somatotrophs and corticotrophs. Among these, one of the first described is the GnRH-stimulated prolactin release by lactotrophs, ${ }^{39}$ an effect that is mediated by the release of a still uncharacterized molecule from immature postnatal gonadotrophs. ${ }^{40}$ In immature cells, GnRH also elicits a biphasic hormone release response on somatotrophs that begins with inhibition of growth hormone secretion during $\mathrm{GnRH}$ application and is followed by a rapid rebound secretion of GH that slowly returns to basal levels. These interactions might be partially related to developmental roles that GnRH may have on these cell types. Some of the candidate paracrine factors from gonadotrophs thought 
to be involved in the development of lactotrophs are the glycoprotein hormone $\alpha$-subunit, the growth factor TGF- $\alpha$ and prolactinreleasing peptide (PrRP). Stimulatory paracrine interactions must be counterbalanced with inhibitory ones for the gland to meet and maintain homeostasis throughout different physiological stages; one good example of negative interaction between gonadotrophs and lactotrophs is that mediated by calcitonin (and calcitonin-like peptides). Calcitonin immunoreactivity is primarily located in gonadotrophs that are associated with cup-shaped lactotrophs (described later in this section). It inhibits basal and TRH-stimulated prolactin synthesis and release as well as lactotroph mitosis. This paracrine effect is likely mediated by the release of TGF- $\beta 1$ by lactotrophs, which in turn inhibits lactotroph proliferation as well as prolactin expression and secretion. ${ }^{41}$ Consistent with this role, estradiol, a well-known promoter of lactotroph secretory activity and proliferation, negatively regulates calcitonin expression in gonadotrophs. Positive and negative interactions have also been described between gonadotrophs and corticotrophs; calcitonin gene-related peptide accounts for the former whereas the natriuretic peptides (ANP and $\mathrm{CNP}$ ) and adrenomedullin (a calcitonin peptide family member) account for the latter. Since stress responses are attenuated in pregnancy and lactation, it is likely that the inhibitory tone of natriuretic peptides on corticotroph function is upregulated during these states of elevated estradiol levels in plasma as estrogens are known to upregulate natriuretic peptide expression in heart tissue.

p0255 Gonadotrophs can also be paracrine targets themselves. Although inhibition of ovulation during lactation is achieved primary by endorphin-mediated inhibition of hypothalamic GnRH neurons triggered by the suckling stimulus, local inhibitory cues from lactotrophs and corticotrophs to gonadotrophs at the anterior pituitary may contribute to the suckling-induced negative influence on ovulation. Increased release of $\beta$-endorphin and galanin by corticotrophs and lactotrophs, respectively, may contribute to inhibit preovulatory LH secretion. In pregnancy, estrogen-induced high galanin release by lactotrophs underlies increased lactotroph activity and growth as well as decreased LH release. During stress and undernutrition, stress-induced activation of the hypothalamo-pituitary-adrenal (HPA) axis inhibits the hypothalamo-pituitary-gonadal (HPG) axis. At the pituitary level, this negative influence of the HPA onto the HPG axis may be mediated by the negative paracrine signals of corticotroph $\beta$-endorphin on GnRHinduced gonadotroph LH release.

At the heart of the structure and function of the anterior pituitary gland is the key supportive and dynamic role of the FS cells. These cells are also excitable and are thought to coordinate activity of endocrine cells. They form two microanatomical structures that may have a large impact on pituitary cell physiology. Located in the center of the hormonal cell cord, they are often arranged in clusters and form small follicles in rats, but are larger in humans and some other species. In the follicles, numerous microvilli protrude and some cilia are present. Follicle-forming FS cells are polarized. At the apical pole, bordering the follicle, they form tight junctions among each other, although not always fully sealed, and, more laterally, junctions of the "zonula adherens" type (desmosomes). The basolateral side makes contact with the endocrine cells and with other FS cells, and extends processes that end on the basal membrane surrounding the cell cords. The role of follicles remains unclear but the structures are thought to be involved in intercellular transport of metabolic products and ions. A second group of FS cells extends long processes between the hormonal cell types within each glandular cell cord. Although these processes 
form intercellular junctions among each other, mostly of the zonula adherens-type, they are also electrotonically coupled through gap junctions as shown by rapid propagation of $\mathrm{Ca}^{2+}$ currents over long distances in the gland. ${ }^{42}$ On this basis, it is hypothesized that these cells coordinate the activity of endocrine cells. In support of this is the finding of a correlation between the number of gap junctions and reproductive maturation in the rat. Interestingly, estradiol seems to increase FS network connectivity, as a steep rise in gap junction number is observed at the end of pregnancy and during lactation. Moreover, in the estrous cycle, connectivity is highest during proestrus and estrus, and it has been recently suggested that this increased connectivity plays a significant role in the preovulatory LH surge. ${ }^{43}$ Some FS cells make intimate foot processes with the basal membrane of the extra-vascular spaces at the periphery of the cell cords. In some species FS cells located in the periphery of the cell cords are juxtaposed in a way that they form sinusoid-like spaces. Intercellular lacunae are also often seen between endocrine cells. These lacunae, along with the sinusoid-like spaces surrounded by FS cells and perivascular spaces are thought to form a micro-channel system within the pituitary, through which hormones, local factors, nutrients, ions and waste products can circulate. The three-dimensional architecture of FS cells is under developmental control: in the infant rat, the FS follicles are elongated and participating FS cells have a columnar shape without cellular extensions and displaying very few junctions. At the onset of puberty, they separate into smaller follicular units and start making extensions and junctions, especially tight junctions.

p0265 It is thus reasonable to hypothesize that FS cells play key roles in anterior pituitary adaptation to varying physiological conditions, including immune, nutritional and other stresses in which they may operate as critical interfaces in homeostatic mechanisms. Prolonged pituitary activation during immune stress, pregnancy, lactation, starvation and other conditions, may lead to excess production of specific hormones that in turn may result in inhibition of essential physiological processes. In such events, it is likely that FS cells provide a mechanism to circumvent this issue through their capability to blunt many stimulated activities in the anterior pituitary. FS cells release NO that in turn may stimulate guanylyl cyclase activity and increase cyclic guanosine monophosphate (cGMP) in different endocrine cell types to inhibit hormone release (Figure 2.3). In addition, FS cells are permissive for the mitogenic effect of estradiol on lactotrophs by releasing fibroblast growth factor-2 (FGF-2), and mediate the stimulatory action of bacterial endotoxin lipopolysaccharide (LPS), tumor necrosis factor $\alpha$ (TNF- $\alpha)$, VIP, PACAP and interleukin-1 (IL-1) on ACTH secretion by releasing IL-6 which act in corticotrophs in a paracrine fashion (Figure 2.3). FS cells may possibly modulate responses to immune stress as they express receptors for epinephrine, acetylcholine, angiotensin II, calcitonin and ATP that are known to regulate immune cell functions. Indeed, FS cells also express glucocorticoid receptors and have been shown to mediate the glucocorticoid fast negative feedback effect on ACTH (and also prolactin and $\mathrm{GH})$ secretion via ATP-binding cassette (ABC) transporter-mediated externalization of annexin 1, which in turn acts on specific binding sites on endocrine cells to inhibit hormone release $^{44}$ (Figure 2.3).

\section{PLASTICITY OF ANTERIOR PITUITARY CELL NETWORK ORGANIZATION AND FUNCTION}

The architecture of the anterior lobe is based on interlacing strands of mostly polygonal cells separated by a tremendously developed 


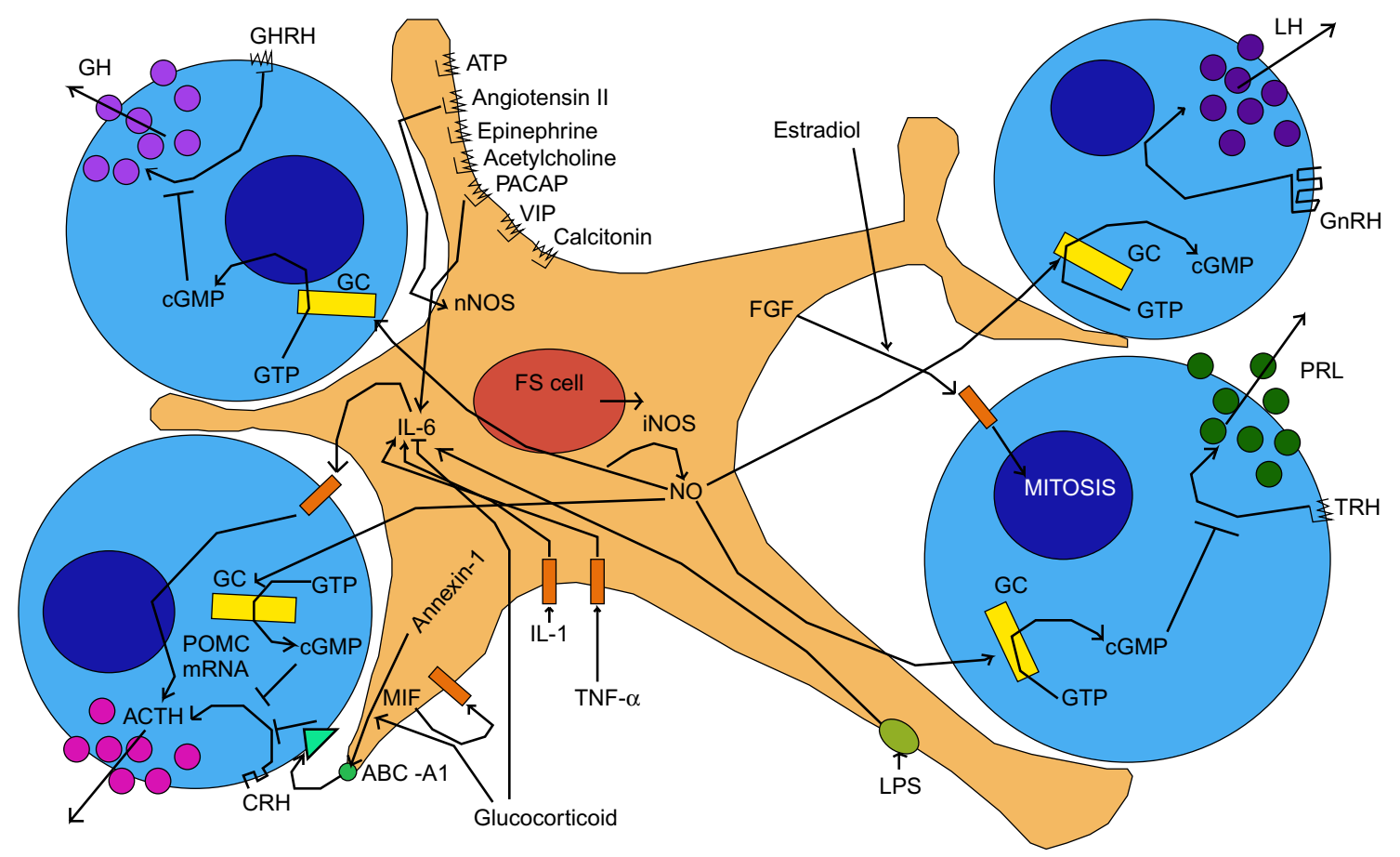

f0020 FIGURE 2.3 Schematic representation of some of the paracrine interactions thought to occur between folliclostellate (FS) cells, lactotrophs, somatotrophs, gonadotrophs and corticotrophs. $\rightarrow$, stimulatory effect; l, inhibitory effect (see text for details).

array of sinusoidal capillaries. Early descriptions of the microanatomy of the adenohypophysis suggested that its various cell types are intermingled, forming cell networks (reviewed in refs $^{35,42}$ ). Nakane later made the seminal observation that the different pituitary cell types are not distributed homogeneously over the various areas of the gland and within a specific cell cord. ${ }^{45}$ In fact, a recent study using two-photon microscopy imaging of genetically engineered mouse somatotrophs expressing the enhanced green-fluorescent protein (EGFP) showed that GH-producing cells are interconnected via adherens junctions, seeming to form a "homotypic connected 3D cell continuum" that displays coordinated $\mathrm{Ca}^{2+}$ transients. ${ }^{46}$ This cell system consists of numerous intercrossing strands of single $\mathrm{GH}$ cells, with larger clusters of $\mathrm{GH}$ cells positioned at the intersection of the cords. Consistent with Nakane's observation, there are differences in the GH cell strand and cluster densities in different regions of the gland. Across the lifespan, the GH system architecture shows plasticity. ${ }^{46}$ In prepubertal animals, the patterning of the GH cell system is similar between the lateral and the median zones of the gland. From puberty to adulthood there is a marked increase in the proportion of $\mathrm{GH}$ cells in clusters in the lateral portions of the gland than in the median zone surrounding the stalk. Interestingly, the volume-to-surface ratios of the GH cell system returns to prepubertal values in the lateral zones of aged mice, indicating that the plasticity of this cell system continues well into adulthood. ${ }^{46}$ More recently, it has been shown that gonadotrophs exhibit significantly different distributions across 
physiological states, ${ }^{47}$ so it is likely that other cell types share a similar cell system architecture and plasticity. In fact, Nakane had observed close associations between somatotrophs and corticotrophs and between gonadotrophs and lactotrophs. Some of the lactotrophs embraced the oval-shaped gonadotrophs with long cellular processes and Nakane named them "cup-shaped" PRL cells. ${ }^{45}$ These cell-cell associations are thought to have functional consequences, not only in the cells involved in the association, but also in the pituitary gland as a whole. That the different cell types are both structurally and functionally interconnected is confirmed by the fact that genetic ablation of GH cells dramatically reduced the pituitary content of all hormones. ${ }^{48}$

p0275 Finally, the ample possibilities brought about by interconnectivity at the cellular network level may offer emergent properties that might be critical to anterior pituitary cells to adapt their physiology to suit the prevailing environmental conditions. As interconnected cell populations bestowed with the role of mounting large-scale responses to maintain homeostasis, experience-dependent plasticity may represent an inherent property of these cells. This concept has been recently illustrated in female mice that underwent one or more lactations to repeatedly and selectively stimulate activity of pituitary lactotrophs. ${ }^{49}$ Throughout the lactotroph population, each lactation event induced alterations in functional connectivity through changes in structural connectivity mediated by differential homotypic lactotroph-lactotroph gap junctional contacts. Following weaning, the lactotroph population is able to maintain the pattern of functional connectivity for weeks to months, a hallmark of long-term experiencedependent plasticity that is reminiscent to that observed in neurons. Likewise, the lactotroph network retains functional connectivity through changes in the extent and strength of cell-cell communication, allowing repeated lactation demands to be met with evolved network dynamics and improved tissue output. ${ }^{49}$ Thus, experience-dependent plasticity allows lactotrophs to adapt their hormone releasing activity upon repeated stimulation, a feature that is likely shared by other endocrine cells within the anterior pituitary and, possibly, throughout the body.

\section{CONCLUDING REMARKS}

Endocrine cells of the anterior pituitary have a remarkably varied signaling toolkit at their disposal which, in combination with GPCR expression profiles, and gap junctional electrical coupling, may allow incoming signals to be processed and propagated from cell to cell in a specific manner. Not only are these features subject to dynamic changes according to physiological needs, but also the morphological arrangement and functional connectivity of the different cell types of this gland can also go through profound remodeling. These fundamental features allow anterior pituitary cells to adapt their responses to environmental challenges and demands and thereby to meet their vital role in homeostatic control.

\section{Acknowledgements}

The authors wish to gratefully acknowledge Jose AriasCristancho for preparing Figures 2 and 3 of this chapter as well as the support provided by National Institute of Health grant DK-43200.

\section{References}

1. Gonzalez-Iglesias AE, Freeman ME. Brain control over pituitary gland hormones. In: Pfaff DW, editor. Neuroscience in the 21st Century. New York: SpringerVerlag; 2012.

2. Ooi GT, Tawadros N, Escalona RM. Pituitary cell lines and their endocrine applications. Mol Cell Endocrinol 2004;228:1-21. 
3. Walker JJ, Terry JR, Tsaneva-Atanasova K, Armstrong SP, Mc Ardle CA, Lightman SL. Encoding and decoding mechanisms of pulsatile hormone secretion. I Neuroendocrinol 2010;22:1226-38.

4. Melmed S. Update in pituitary disease. J Clin Endocrinol Metab 2008;93:331-8.

5. Perez-Castro C, Renner U, Haedo MR, Stalla GK, Arzt E. Cellular and molecular specificity of pituitary gland physiology. Physiol Rev 2012;92:1-38.

6. Roudbaraki M, Lorsignol A, Langouche L, Callewaert G, Vankelecom H, Denef C. Target cells of gamma3-melanocyte-stimulating hormone detected through intracellular $\mathrm{Ca}^{2+}$ responses in inmature rat pituitary constitute a fraction of all main pituitary cell types, but mostly express multiple hormone phenotypes at the messenger ribonucleic acid level. Refractoriness to melanocortin-3 receptor blockade in the lacto-somatotroph lineage. Endocrinology 1999;140:4874-85.

7. Villalobos C, Nuñez L, Frawley S, García-Sancho J, Sánchez A. Multi-responsiveness of single anterior pituitary cells to hypothalamic-releasing hormones: a cellular basis for paradoxical secretion. Proc Natl Acad Sci USA 1997;94:14132-7.

8. Childs GV. Development of gonadotropes may involve cyclic transdifferentiation of growth hormone cells. Arch Physiol Biochem 2002;110:42-9.

9. Stojilkovic SS. Molecular mechanisms of pituitary endocrine cell calcium handling. Cell Calcium 2012;51:212-21.

10. Stojilkovic SS, Tabak J, Bertram R. Ion channels and signaling in the pituitary gland. Endocr Rev 2010;31:845-915.

11. van Goor F, Zivadinovic D, Martínez-Fuentes AJ, Stojilkovic SS. Dependence of pituitary hormone secretion on the pattern of spontaneous voltage-gated calcium influx. Cell type-specific action potential secretion coupling. J Biol Chem 2001;276:33840-6.

12. Kretschmannova K, Kucka M, Gonzalez-Iglesias AE, Stojilkovic SS. The expression and role of hyperpolarization-activated and cyclic nucleotidegated channels in endocrine anterior pituitary cells. Mol Endocrinol 2012;26:153-64.

13. Liang Z, Chen L, McClafferty H, Lukowski R, MacGregor D, King JT, et al. Control of hypothalamicpituitary-adrenal stress axis activity by the intermediate conductance calcium-activated potassium channel, SK4. J Physiol 2011;589:5965-86.

14. Tsaneva-Atanasova K, Sherman A, van Goor F, Stojilkovic SS. Mechanism of spontaneous and receptor-controlled electrical activity in pituitary somatotrophs: experiments and theory. J Neurophysiol 2007;98:131-44.
15. Gonzalez-Iglesias AE, Jiang $\mathrm{Y}$, Tomic M, Kretschmannova K, Andric SA, Zemkova H, et al. Dependence of electrical activity and calcium influxcontrolled prolactin release on adenylyl cyclase signaling pathway in pituitary lactotrophs. Mol Endocrinol 2006;20:2231-46.

16. Tougard C, Tixier-Vidal A. Lactotropes and gonadotropes. In: Knobil E, Neill JD, editors. The physiology of reproduction. New York: Raven Press Ltd; 1994. p. 1711-47.

17. Childs GV. Gonadotropes and lactotropes. In: Neill JD, editor. Knobil and neill's physiology of reproduction. 3rd ed. New York: Raven Press Ltd; 2006. . p. 1483-562..

18. Christian HC, Chapman LP, Morris JF. Thyrotrophinreleasing hormone, vasoactive intestinal peptide, prolactin-releasing peptide and dopamine regulation of prolactin secretion by different lactotroph morphological subtypes in the rat. I Neuroendocrinol 2007;19:605-13.

19. Tabak J, Tomaiuolo M, Gonzalez-Iglesias AE, Milescu LS, Bertram R. Fast-activating voltage- and calciumdependent potassium (BK) conductance promotes bursting in pituitary cells: a dynamic clamp study. J Neurosci 2011;31:16855-63.

20. Tomaiuolo M, Bertram R, Gonzalez-Iglesias AE, Tabak J. Investigating heterogeneity of intracellular calcium dynamics in anterior pituitary lactotrophs usign a combined modelling/experimental approach. J Neuroendocrinol 2010;22:1279-89.

21. van Goor F, Zivadinovic D, Stojilkovic SS. Differential expression of ionic channels in rat anterior pituitary cells. Mol Endocrinol 2001;15:1222-36.

22. van Goor F, Li YX, Stojilkovic SS. Paradoxical role of large-conductance calcium-activated $\mathrm{K}+(\mathrm{BK})$ channels in controlling action potential-driven $\mathrm{Ca} 2+$ entry in anterior pituitary cells. J Neurosci 2001;21:5902-15.

23. Tabak J, Toporikova N, Freeman ME, Bertram R. Low dose of dopamine may stimulate prolactin secretion by increasing fast potassium currents. J Comput Neurosci 2007;22:211-22.

24. Simasko SM, Sankaranarayanan S. Characterization of a hyperpolarization-activated cation current in rat pituitary cells. Am J Physiol - Endocrinol Metab 1997;272: E405-14.

25. Gonzalez-Iglesias AE, Kretschmannova K, Tomic M, Stojilkovic SS. ZD7288 inhibits exocytosis in an HCNindependent manner and downstream of voltage-gated calcium influx in pituitary lactotrophs. Biochem Biophys Res Commun 2006;346:845-50.

26. Tian L, Shipston MJ. Characterization of hyperpolarization-activated cation currents in mouse anterior pituitary, AtT20 D16:16 corticotropes. Endocrinology 2000;141:2930-7.

CELLULAR ENDOCRINOLOGY IN HEALTH AND DISEASE 
27. Christensen HR, Zeng Q, Murawsky MK, Gregerson KA. Estrogen regulation of the dopamine-activated GIRK channel in pituitary lactotrophs: implications for regulation of prolactin release during the estrous cycle. Am J Physiol - Regul Integr Comp Physiol 2011;301: R746-56.

28. Gregerson KA. Functional expression of the dopamineactivated $\mathrm{K}+$ current in lactotrophs during the estrous cycle in female rats. Endocrine 2003;20:67-74.

29. Andric SA, Zivadinovic D, Gonzalez-Iglesias AE, Lachowicz A, Tomic M, Stojilkovic SS. Endothelininduced, long lasting, and Ca2 + influx-independent blockade of intrinsic secretion in pituitary cells by $\mathrm{Gz}$ subunits. J Biol Chem 2005;280:26896-903.

30. Gonzalez-Iglesias AE, Murano T, Li S, Tomic M, Stojilkovic SS. Dopamine inhibits basal prolactin release in pituitary lactotrophs through pertussis toxinsensitive and -insensitive signaling pathways. Endocrinology 2008;149:1470-9.

31. Berridge MJ. Neuronal signalling. Cell signaling biology. Portland Press Limited; 2012. p. 10.1-10.104

32. Li YX, Rinzel J, Keizer J, Stojilkovic SS. Calcium oscillations in pituitary gonadotrophs: comparison of experiment and theory. Proc Natl Acad Sci USA 1994;91:58-62.

33. Vergara LA, Stojilkovic SS, Rojas E. GnRH-induced cytosolic calcium oscillations in pituitary gonadotrophs: phase resetting by membrane depolarization. Biophys J 1995;69:1606-14.

34. Kukuljan M, Vergara L, Stojilkovic SS. Modulation of the kinetics of inositol 1,4,5-trisphosphate-induced $[\mathrm{Ca} 2+]$ i oscillations by calcium entry in pituitary gonadotrophs. Biophys J 1997;72(2 Pt 1):698-707.

35. Denef C. Paracrinicity: the story of 30 years of cellular pituitary crosstalk. J Neuroendocrinol 2008;20:1-70.

36. Kirk SE, Dalkin AC, Yasin M, Haisenleder DJ, Marshall JC. Gonadotropin-releasing hormone pulse frequency regulates expression of pituitary follistatin in folliculostellate cell-enriched primate pituitary cell cultures. Endocrinology 1994;135:876-80.

37. Stojilkovic SS, He ML, Koshimizu TA, Balik A, Zemkova H. Signaling by purinergic receptors and channels in the pituitary gland. Mol Cell Endocrinol 2010;314:184-91.

38. Szabo M, Cuttler L. Differential responsiveness of the somatotroph to growth hormone-releasing factor during early neonatal development in the rat. Endocrinology 1986;118:69-73.

39. Denef C, Andries M. Evidence for paracrine interaction between gonadotrophs and lactotrophs in pituitary cell aggregates. Endocrinology 1983;112:813-22.

40. Andries M, Denef C. Gonadotropin-releasing hormone influences the release of prolactin and growth hormone from intact rat pituitary in vitro during a limited period in neonatal life. Peptides 1995;16:527-32.

41. Sarkar DK, Kim KH, Minami S. Transforming growth factor-beta 1 messenger RNA and protein expression in the pituitary gland: its action on prolactin secretion and lactotropic growth. Mol Endocrinol 1992;6:1825-33.

42. Hodson DJ, Romano N, Schaeffer M, Fontanaud P, Lafont C, Fiordelisio T, et al. Coordination of calcium signals by pituitary endocrine cells in situ. Cell Calcium 2012;51:222-30.

43. Lyles D, Tien JH, McCobb DP, Zeeman ML. Pituitary network connectivity as a mechanism for the luteinizing hormone surge. J Neuroendocrinol 2010;22:1267-78.

44. Morris JF, Christian HC, Chapman LP, Epton MJ Buckingham JC, Ozawa $\mathrm{H}$, et al. Steroid effects on secretion from subsets of lactotrophs: role of FolliculoStellate cells and Annexin 1. Arch Physiol Biochem 2002;110:54-61.

45. Nakane PK. Classifications of anterior pituitary cell types with immuno-enzyme histochemistry. J Histochem Cytochem 1970;18:9-20.

46. Bonnefont X, Lacampagne A, Sanchez-Hormigo A, Fino E, Creff A, Mathieu MN, et al. Revealing the large-scale network organization of growth hormonesecreting cells. Proc Natl Acad Sci USA 2005;102:16880-5.

47. Alim Z, Hartshorn C, Mai O, Stitt I, Clay C, Tobet S, et al. Gonadotrope plasticity at cellular and population levels. Endocrinology 2012;153:4729-39.

48. Waite E, Lafont C, Carmignac D, Chauvet N, Coutry N, Christian H, et al. Different degrees of somatotroph ablation compromise pituitary growth hormone cell network structure and other pituitary endocrine cell types. Endocrinology 2010;151:234-43.

49. Hodson DJ, Schaeffer M, Romano N, Fontanaud P, Lafont C, Birkenstock J, et al. Existence of long-lasting experience-dependent plasticity in endocrine cell networks. Nat Commun 2012;3:605.

CELLULAR ENDOCRINOLOGY IN HEALTH AND DISEASE 